\title{
Disposition Continuation
}

National Cancer Institute

\section{Source}

National Cancer Institute. Disposition Continuation. NCI Thesaurus. Code C83057.

An indication or description that the subject will be continuing on to next phase of the trial. 